\title{
The translation task: ITCR students with no expertise in translation
}

\author{
La tarea de traducir: \\ Una experiencia con estudiantes aficionados de traducción en el ITCR
}

\author{
Yohanna Abarca Amador \\ Escuela de Ciencias del Lenguaje \\ Instituto Tecnológico de Costa Rica
}

\begin{abstract}
As an English teacher at the Costa Rica Institute of Technology, I often see students from the Engineering and Business Administration majors struggling to understand study materials and professional articles in English. Even though the students do not have any training in translation, they have to do this task in their regular classes. They usually use printed dictionaries or computer-assisted translation tools that have been designed for these purposes and that they can access. This observation led, as a result, to the interest in finding out if the students are really able to understand and translate a text from English to Spanish accurately. The translations are analyzed at the word, phrase and sentence levels to examine the comprehension level of the text and the quality of their translations.
\end{abstract}

Keywords: computer-assisted translation, amateur translation, English Proficiency, equivalence, source language, target language, translation tools

\section{Resumen}

Como docente de Inglés del Instituto Tecnológico de Costa Rica, observo diariamente a los estudiantes de las distintas carreras de Ingeniería y Administración de Empresas en sus esfuerzos para entender materiales de estudio y artículos profesionales en este idioma. Aunque no tienen ningún entrenamiento en traducción, deben realizar esta tarea en sus clases regulares valiéndose de herramientas como diccionarios impresos o tecnologias digitales para este fin. A raíz de estas observaciones, surge el interés por investigar si los alumnos realmente son capaces de entender y traducir de manera precisa y efectiva un texto escrito en inglés al español. Se analizará la traducción al nivel de palabras, frases y oraciones completas con el fin de comprobar el nivel de compresión y la calidad de la traducción realizada. 
Palabras clave: traducción asistida por computadora, traducción amateur, conocimiento del Inglés, equivalencia, lengua fuente, lengua meta, herramientas de traducción

\section{Introduction}

A $\mathrm{s}$ an English major in the early 1990s, one of the most difficult tasks in my learning process of the English language was trying to find the meaning of foreign words and sentences. At the beginning levels, this was certainly hard for I had a very limited scope of vocabulary and grammar structures in English. As I advanced in my studies and my English level improved, I faced a more difficult task to achieve: I had to be coherent and cohesive in my oral and written work.

As suggested by Richards, Platt \& Platt (1992), coherence involves the relationships which link the meaning of the sentences in a text. These links may be based on the speakers' shared knowledge. On the other hand, cohesion is the grammatical and/or lexical relationships between the different elements of a text. This may be the relationship between different sentences or between different parts of a sentence.

I often had to choose the most appropriate meaning of a word to fit it in a particular sentence or text. In those instances, I would search for words in a number of dictionaries. Incidentally, at that time, books and dictionaries were the tools I used when I did not know the meaning of certain words. Computers were a limited and inaccessible technology. The Internet was just beginning to be used and online dictionaries or translators were not yet available.

Although I did not have the capacity to use the above technological tools at that moment, one tool did become fundamental: prior or background knowledge. As stated by Tapiero (2007), prior knowledge can be understood as the reader's activation of stereotyped or "schema-like" knowledge which is assumed to lead to the correct interpretation of a text. The activation of these knowledge structures enables readers to reach a deep level of textual interpretation. Without even noticing, I was translating with the aid of my background knowledge, the skills I had acquired in English and the use of books and printed dictionaries.

However, my translation tasks were done at the amateur level, since I was not a professional translator, capable of producing texts that read well in the target language. Professional translators are fluent in both the source and target language. Later, when I became a college English language instructor in different universities, I noticed my students' struggle to find the meaning of unknown vocabulary and sentences, just like me at the beginning of my English major.

Nowadays, however, students can count on a large number of computer tools and applications which can aid them to find and understand the meaning of words and sentences. 
They just enter an unfamiliar word or phrase into an online dictionary or translator on their mobile phones and get the corresponding equivalence in the target language almost immediately. Still, I have often noticed that these tools are not enough to grasp on their own the right translation of a word in a given context. It is a fact that both online translators and digital dictionaries are more helpful at the word or phrase level than the contextual level.

Undoubtedly, the students' internalized background knowledge, plus their proficiency level in the target language are also essential in the process of translating from the second (source) language into their native (target) language. As a case in point, students at the Costa Rica Institute of Technology (ITCR), who are not English majors and do not usually have experience in professional translation, face the task of translating mostly technical texts from English to Spanish in a number of courses, as amateur translators.

Thus, the present study seeks to find out whether these students are able to understand a paragraph written in English and translate it into Spanish meaningfully and effectively.

\section{The Translation Task}

Throughout history people have asked the question: "How do you say 'this' in ' $\mathrm{X}$ ' language?" The answer is not quite a simple one due to the fact that since words in the source language do not often have exact equivalents in target languages. In this respect, Paz (1971) claims that all texts, being part of a literary system, descended from and related to other systems, are translations of translations of translations.

Translation has been defined in different ways through history. Many scholars define it as a human skill, not a mechanical one, not a science, but an art. Petrelli (2003) argues that to translate is not to codify or decipher but to interpret. Yet, Newmark (2003) claims that "translation is concerned with moral and factual truth. This truth can be effectively rendered only if it is grasped by the reader, and that is the purpose and the end of translation." On the other hand, Gouadec (2007) anticipates any definition of translation and points out that the first step to translate is to understand the text. This requires general and close reading to get the gist of the text.

For Gouadec, translation is a process. Therefore, there are different levels and steps the translator has to follow to achieve a successful product or output in this process. To this end, the translator may have to use encyclopedias, textbooks and scholarly papers in order to understand the concepts or subjects in the source language text. After this general reading, then comes the close reading step. At this point, the translator is expected to find the words in context to make sure that they are not being misinterpreted and later end up rendering a faulty translation.

Newmark (2003) mentions four levels that the translator has to consider when doing this task. First, the source language level of the text. The translator constantly has to go back to the language level to match the original as closely as possible. Second, the referential level. It deals with the events and objects either real or imaginary in the text which are essential for the 
comprehension of the target language text. Third, the cohesive level. This level refers to the grammatical part, the ideas, and the tone of the text. This is a more general level, which gives an overall picture of the text. Sometimes the language level has to be adjusted to make it comprehensible to the reader. Fourth, the level of naturalness deals with the use of common language appropriate to the writer or the speaker in a certain situation. This level is concerned only with reproduction. Consequently, a revision procedure must follow the translation task.

\section{Professional Translation}

To be a translator requires an expert level of knowledge of at least two languages: the source language, the language out of which a translation is made and the target language, the language into which a translation is made (Richards, Platt and Platt, 1996). Professional translators function as a "bridge" between the languages they work with. That is, they can render the message of the original text, with the appropriate terminology and style, into the target language (Aparicio and Durbay, 2005).

Furthermore, although translators cannot be fully competent in all the fields that they have to deal with in their translation task, they must approximate them in a way that facilitates an accurate understanding of the target text for those who read it. Thus, the translation is said to achieve the transfer of content and form from the original text to the target one. Another important aspect in the translation process is the need to use an appropriate lexicon, that is, the set of all the words and idioms in any language. Schaffner and Adab (2000) contend that translators must always have "a word for it". Therefore, in their need to locate the most appropriate term or phrase sometimes they need to be creative. Yet, this "creativity" must come from the need to accommodate an idea into a new setting. This is one of the most difficult aspects of translating. If a person makes a translation without having much experience, he might fail to transfer the meaning of the source unfaithfully, so to speak, into the target language.

A translator uses two languages both consciously and alternatively. The translator's competence comes from academic studies in the field, expertise in linguistic, textual, encyclopedic and cultural knowledge. Along these lines, the competence profiles of a professional translator and an amateur one show remarkable variations. For instance, Presas (2000) emphasizes that novice translators show very rudimentary transfer mechanisms, frequently consisting of automatic associations, usually restricted to the lexical level. Whereas, the professional translator possesses a knowledge of the two languages involved, knowledge of the world and the written material, the ability to use tools and resources, and cognitive qualities such as creativity and the capacity for problem-solving.

\section{"Amateur" Translation}

Pérez and Susam (2014) point out that translation today is at a stage in which the status of the traditional focus of translators as professionals is no 
longer sufficient for the complex reallife situations in which people are required to do this task. As a result, an increasing number of non-professionals who translate in many different contexts and in more diversified forms has appeared. This phenomenon has emerged as an alternative to established professional practices. Similarly, Izwaini (2012) argues that the advances in technology and communications have also resulted in an expansion of translation beyond its traditional scope and settings. Nowadays, amateur translators engage in the activity by making use of Internet tools developed for this purpose. Consequently, the target text might run the risk of showing gaps at the vocabulary, grammar or discourse levels. This can be detrimental for the quality of the translation.

Many factors can play a significant role in the translation task: the content of the source materials, the dynamics of the translation process, the source languages, and the translator's intervention. These factors are instrumental to the rendering of a quality translation. In many cases, inexperienced translators tend to modify the source text to compensate for the impossibility of producing the right equivalents in the target text.

In our information technology society, great amounts of information need to be translated from one language to another with short due times. Therefore, many people in different areas of work are forced to translate documents without having the expertise to do so. In fact, this led to a phenomenon in the last decades as a result of the growing demand of content to be translated into one more than two languages: "volunteer translation". As a result, different volunteer and collaborative networks have emerged inspired by shared objectives (Folaron, 2010). These groups contribute to the production of multilingual translations that range from "literary texts, multimedia content, social networking sites to open source software applications" (p. 233). Even though, these networks can be valuable, the quality standards that they have do not always correspond to those of a professional translator.

\section{CAT Translation}

A mechanical tool to translate from one language to another has been a dream and a goal of many scholars for many years. In the 17th century, philosophers such as Descartes and Wilkings talked about the idea of converting Universal Languages into numerical codes. Years later, after World War II, Warren Weaver, then vice-president of the Rockefeller foundation, contacted different colleges and universities in the United States to raise the issue of digital computers for translation (Somers, 2003). In the 1950's, many countries invested lots of money on Machine Translation research. In 1964, the US government appointed The Automated Language Processing Advisory Committee (ALPAC) as well. A report by this committee concluded that machine translation was more expensive, less accurate and slower than human translation. They suggested that "machine" aided translation was more feasible in the future.

In the 1970s and 1980s, some translation systems were developed which incorporated ideas from structural 
linguistics and computer science. By the 1980s, researchers recognized that the complete high quality translation of a text was not going to be possible in the near future. After this, the concept of computer-based tools for translators was born. These tools range from word processors to spell checkers, online dictionaries, and online translators among others. Yet, in this regard Barrachina and others (2009) conclude that computerbased translation tools require a human to increase the productivity of the whole translation process. That is, human correction and edition must be incorporated into the translation process itself.

To the present day many online translation products have been launched to be used by professional or amateur translators as well as people in general. Nowadays, computer-assisted translation provides tools to cope with the coherence of the text and the speed with which a translation can be done. Still, CAT does not translate without human intervention. Therefore, the text will always require further human revision due to the fact that computers can scan each word of the source text in their built-in specialized dictionaries, but they do not have the capacity to put the words in context. CAT does provide a series of tools which are useful not only for the professional translator, but also for those who need a quick translation of a sentence, a phrase or a word.

\section{Methodology}

Population. Seven TEC students agreed to participate in translating the passage used for this study in the first semester of the year 2017. They were all business administration majors, and they were from 19 to 25 years old. Besides, all of them were enrolled in English VII for Business Administration, an upper intermediate level course, which is the last English course that they take in the BA program. It should also be noted that none of the students had ever taken a translation course or had ever been involved in a translation task before they were asked to participate in this study. An intermediate student corresponds to a B1 Level, described by the Common European Framework of Reference for Languages (CEFRL) as "the system that defines and explains the different levels of oral and written expression and comprehension for languages such as English." An intermediate student is also described as an independent user of the language. In other words, a person with "the necessary fluency to communicate without effort with native speakers" (British Council, 2018).

\section{Procedures}

The students were asked to fill in a two-part questionnaire. The first part included seven questions related to personal information and previous experience in translating documents from English to Spanish. The second part included three questions related directly to the topic of the text that they were asked to translate. Both the questionnaire and the instructions were given in Spanish to make sure there were not any misunderstandings about the task to be done. (See the questionnaire in Appendix 1).

After answering the questions, the students proceeded to translate the English passage into Spanish. 
They were asked to read the text in its entirety to grasp its content and meaning, and then, organize it into thought units to prevent pitfalls of mistranslation. Also, they were asked to carefully review the context in which the words were used. Furthermore, they were advised to look up words whose meaning they did not know or were unsure of. The subjects were told that they would not be allowed to ask questions during their translation task. Moreover, to make the translation each student received the same dictionary: an English-Spanish dictionary published by Merriam Webster in 2014. They were not allowed to use any online translation tools. The printed dictionary was provided by the author to the students so that all of them could work in equal conditions.

The paragraph chosen for this study was taken from Ornstein, (1991: 187). It was used as a demonstration by Muriel and Schechter at the 1999 national conference of the National Academic Advising Association (NACADA). This is Ornstein's passage used for the demonstration by both researchers:

With hocked gems financing him, our hero bravely defied all scornful laughter that tried to prevent his scheme. "Your eyes deceive," he had said. "An egg, not a table correctly typifies this unexplored planet." Now three sturdy sisters sought proof.
Forging along, sometimes through calm vastness, yet more often very turbulent peaks and valleys, days became weeks as many doubters spread fearful rumors about the edge. At last from nowhere welcome winged creatures appeared, signifying momentous success.

The researchers concluded that the paragraph may seem incomprehensible until the reader makes one connection: Christopher Columbus. One of the requirements for learning is to have background or prior knowledge to which the information can relate, a pre-existing structure that will accommodate the new information. As soon as you find the pre-existing structure, it all makes sense. Having a structure or space ready for new information can be a helpful learning tool. In the present study, Ornstein's text was used for the students' translation. Prior to the task, and along the lines of Muriel and Schechter, they were asked questions to find out to what extend their background knowledge helped them understand the content of the passage.

\section{Analysis of the Results}

Table one shows the results obtained in the first part of the questionnaire given to the students. 
Table 1

Results found in the first part of the questionnaire

Number of students who answered the questionnaire: 7

Question 1: ¿Ha llevado usted cursos de traducción? Sí 0. No 7 students.

Question 2: ¿Si su respuesta es afirmativa en cuál institución? No answers.

Question 3: ¿Ha hecho usted traducciones? Sí 0. No 7 students.

Question 4: Si su respuesta es afirmativa, mencione los temas que ha traducido. No answers.

Question 5: ¿Qué carrera estudia en el Instituto Tecnológico de Costa Rica? 7 students answered that Business Administration.

Question 6: ¿Qué año está cursando? 4 students answered the fourth year and 3 students, the third year.

Question 7: ¿Cuál es su rango de edad? Por favor marque con una "X”.

16-18: 0 students.

19-21: 5 students.

22-25: 2 students.

Note: Data collected by the researcher.

Questions 1 to 4 were designed to (Note: The information provided in know if the students had any previ- questions 5 to 7 has already been menous experience or courses in transla- tioned in the Methodology section).

tion. It was found out that none of Table 2 shows the results obtained them had ever translated a text or in the second part of the questionnaire. taken a course in translation before.

Table 2

Results found in the second part of the questionnaire

Number of students who answered the questionnaire: 7

Question 1: ¿A qué personaje de la historia se refiere este párrafo?

One student said he did not know.

Three students did not answer the question.

Two students said the character was a hero.

One student said Christopher Columbus.

Question 2: ¿A qué acontecimiento histórico se refiere este párrafo?

Three students did not answer the question.

One student answered the Bible.

Two students said they did not know.

One student answered that it referred to the discovery of the Earth as a round planet. 
Question 3: ¿Qué partes del párrafo le han ayudado a inferir el nombre del personaje o hecho al que se refiere este párrafo?

Two students did not answer.

One student said the first three lines of the paragraph.

One student said the line "Our hero bravely defied" was the key to know the character and the event.

One student said the phrases "the three sisters and the unexplored planet".

One student answered the phrase "rumors about the edge".

One student said the passage in general had help him to know who it was talking about.

Note: Data collected by the researcher.

In question 1,5 students did not know who the character of the story was. One student answered that he was a hero, and only one correctly identified the character as Christopher Columbus, who the historical character is referred to in the source text. In question 2, 5 students did not know the event referred to in the passage. One student answered the Bible and one said that it talked about "the discovery that the Earth was not flat but round". In question 3,2 students did not answer the question. The rest of the students mentioned that different phrases or sentences in the passage helped them know what it was about. In this second part of the questionnaire shows that, although most of the students did not correctly guessed the specific event or character of the text, they used their previous knowledge to understand the meaning of the text.

Furthermore, the students correctly interpreted that the passage dealt with a past event. In fact, one student correctly answered that the character of the passage was Christopher Columbus. Another student added that the phrase "the edge" referred to the idea that the earth was not round but flat, an equivalence which is consistent with the event described in the passage. These answers show that some students were able to interpret the text beyond what was literally written in it. 


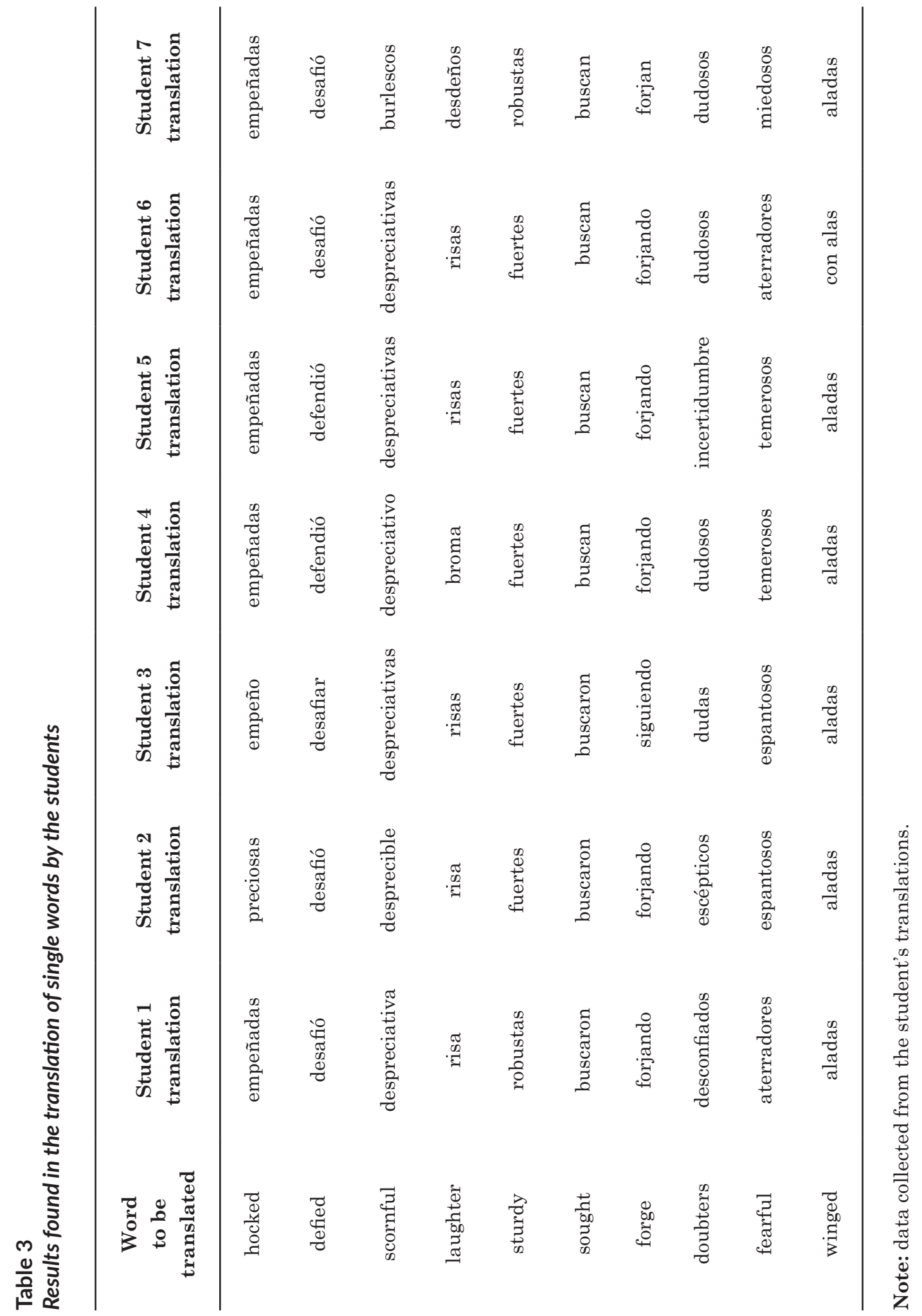


Table 3 shows the results found in the translation of ten words from the text which were used to analyze the quality of the translation done by the student at the basic or word level. These words are not common and they had to be contextualized in order to find the most appropriate meaning for them. Gouadec (2007) mentions that "in any challenging text, the translator needs to find the words out of and in context to make sure that they are not being misinterpreted." At the word level, many of the students worked only with the definition given by the dictionary. These students actually approximated the meaning of the word in context more accurately than the students who used a different definition than the one provided by the dictionary. In fact in most cases when the students used other definitions that were not exactly the one in the dictionary, they resulted in misinterpretations of the words. For example 5 of the 7 students translated the word "hocked" as "empeñadas" which was more appropriate than "empeño" 1 student) and "preciosas"( 1 student). In the case of the word "defied", 4 students used the dictionary definition "desafió" which was also more appropriate than the translations "desafiar", (1 student) and "defendió" (2 students). The same result is observed in the 10 words that were used to analyze the translations at the word level. It can be concluded that the students, as amateur translator at an intermediate language level, do not have yet the lexical corpus necessary to fulfill a translation process more effectively.

Table 4

Results found in the translation of phrases by the students

\begin{tabular}{ccccc}
\hline $\begin{array}{c}\text { Phrases } \\
\text { translated by } \\
\text { the students }\end{array}$ & Hocked gems & $\begin{array}{c}\text { Scornful } \\
\text { laughter }\end{array}$ & Sturdy sister & Calm vastness \\
\hline Student 1 & gemas & risa & hermanas & la inmensidad \\
& empeñadas & despreciativa & robustas & de la calma \\
Student 2 & piedras preciosas & risa despreciable & fuertes & una inmensa \\
& hermanas & tranquilidad \\
Student 3 & el empeño de & risas desprecia- & fuertes herma- & la inmensidad \\
& las gemas & tivas & nas & del pensamiento \\
Student 4 & las joyas & en broma & fuertes & una calmada \\
& empeñadas & & hermanas & inmensidad
\end{tabular}




\begin{tabular}{|c|c|c|c|c|}
\hline Student 5 & $\begin{array}{c}\text { gemas } \\
\text { empeñadas }\end{array}$ & $\begin{array}{c}\text { risas } \\
\text { despreciativas }\end{array}$ & $\begin{array}{c}\text { fuertes } \\
\text { hermanas }\end{array}$ & inmensa calma \\
\hline Student 6 & $\begin{array}{c}\text { gemas } \\
\text { empeñadas }\end{array}$ & $\begin{array}{c}\text { risas } \\
\text { despreciativas }\end{array}$ & $\begin{array}{c}\text { fuertes } \\
\text { hermanas }\end{array}$ & inmensa calma \\
\hline Student 7 & $\begin{array}{c}\text { gemas } \\
\text { empeñadas }\end{array}$ & $\begin{array}{l}\text { los desdeños } \\
\text { burlescos }\end{array}$ & $\begin{array}{l}\text { robustas } \\
\text { hermanas }\end{array}$ & $\begin{array}{c}\text { la calma } \\
\text { inmensidad }\end{array}$ \\
\hline
\end{tabular}

Note: data collected from the student's translations.

Table 4 shows four phrases from the passage that were used to analyze the output of the at the phrase level. It can be noticed that the majority of the students also used the dictionary definitions at this level. For instance, for the translation of "hocked gems", 4 students used "gemas empeñadas". Also, for the phrase "scornful laughter", 5 students used "risa despreciativa" or the plural form "risas despreciativas". For "sturdy sister", 5 students chose "fuertes hermanas" Finally, for the phrase "calm vastness", two students used "inmensa calma".

When the students came up with definitions different from those provided by the dictionary that they were given for the task, they showed more problems of interpretation and produced more wrong word order. For example, the phrase "hocked gems" was translated by one student as "el empeño de las gemas," an equivalence that is quite misleading to the reader. Another example of this was the translation of the phrase "scornful laughter". One student translated this phrase as "los desdeños burlosos," and another student translated it as "en broma". These two translations are not appropriate for the context of the text. In fact, the word,"burlosos" is not registered as a Spanish word according to the dictionary of the Real Academia Española de la Lengua (DRAE). Finally, the phrase "calm vastness" was translated by one student as "la inmensidad del pensamiento," which is not a right equivalent in the target text. Again, one cannot argue this student's intentions while using "pensamiento." One could argue that he wanted to sound poetic. Yet, if he did not use the dictionary at all, this equivalence in the target language reflects that the student's proficiency in both languages does not suffice to produce the expected equivalence. Should the student be fluent in both languages, Spanish and English in the case of this study, a more accurate translation for "calm vastness" could be expected. 
Table 5

Results found in the translation of sentences 1 and 5 by the students

\section{Sentences from the source passage:}

1. "With the hocked gems financing him, our hero bravely defied all scornful laughter that tried to prevent his scheme."

5. "At last, from nowhere winged creatures appeared signifying momentous success."

\section{Student 1}

1. "Con las gemas empeñadas financiándolo, nuestro héroe desafió valientemente toda risa despreciativa que intentó evitar su plan."

5. "Por fin, de la nada aparecieron creaturas aladas indicando éxito fatídico."

\section{Student 2}

1. "Con la financiación de las piedras preciosas (gemas), nuestro héroe desafió toda risa despreciable que trató de evitar su proyecto."

5. "Al final, de algún lugar aparecieron creaturas aladas."

\section{Student 3}

1. "Con el empeño de las gemas él obtuvo financiamiento, nuestro valiente héroe que desafió las risas despreciativas que trataron de evitar su proyecto."

5. "Por último, de algún lugar aparecieron criaturas aladas anunciando el momento del éxito."

\section{Student 4}

1. "Financiándose con las joyas empeñadas, nuestro héroe valientemente defendió superiormente en broma para intentar prevenir este plan."

5. "Por último, desde alguna parte creaturas con alas aparecieron significando un importante éxito."

\section{Student 5}

1. "Con las gemas empeñadas financiándolo, nuestro valiente héroe defendió todas las risas despreciativas que intentan prevenir su plan."

5. "Finalmente, desde ninguna parte creaturas aladas aparecieron significativamente momentos de éxito." 


\section{Student 6}

1. "Financiándose con gemas empeñadas nuestro héroe valientemente desafió todas las risas despreciativas que trataron de prevenir su plan."

5. "Por fin, desde ningún lado, criaturas con alas aparecieron como significado del importante éxito."

\section{Student 7}

1. "Con las gemas empeñadas financiándolo, nuestro valiente héroe desafió todos los desdeños burlosos que trataban de prevenir su plan."

5. Sobre el fin, al menos por ninguna parte creaturas aladas aparecen satisfaciendo un éxito momentoso."

Note: data collected from the student's translations.

Table 5 shows the translation of the first and the last sentence from the passage. These sentences were chosen to analyze the accuracy of the students translation at the sentence level. Both sentences are complex in terms of the lexicon and the syntax and also had important keys to understanding who the character was and the event that the passage referred to.

The translation of complete sentences shoed the majority of variations. Although the students were given the same dictionary, at this level they had to contextualize the words, use the appropriate word order and also the correct syntax according to their own skills of the English language. As emphasized by Presas (2000), translators who are not experienced show very rudimentary transfer mechanisms, consisting of automatic associations, almost always restricted to the lexical level. This affirmation is exemplified by the translation of the sentence "At last, from nowhere winged creatures appeared signifying momentous success" translated as "Sobre el fin, al menos por ninguna parte creaturas aladas aparecen satisfaciendo un éxito momentoso", and: "Finalmente, desde ninguna parte creaturas aladas aparecieron significativamente momentos de éxito." In the two case, the translation was faulty and meaningless.

Furthermore, some words by themselves may be correctly translated in word-by-word translation. Yet, when one looks at the complete sentence, this lacks interpretation and contextualization. Understandably, Izwaini (2012) argues that amateur translators engage in the translation activity by making use of tools as a printed dictionary (in the case of the present study). Still, they might run the risk of showing gaps at the vocabulary, grammar or discourse levels. Consequently, the habit of using a dictionary as the sole resource becomes detrimental to the quality of the translation. On the contrary, a professional translator may look for errors in the translation process, but the amateur translator does not have enough language skills to engage in the process. Thus, the result is an incoherent rendering of the source text. In Izwaini's words, this leads to the "impossibility of producing the right equivalents in the target text." 


\section{Conclusions}

Translation is not a mechanical task. When a person translates, he has to be aware of and look for errors in the translation process. This kind of self- evaluation allows the translator to learn and improve through experience, and it remains a fundamental step that cannot be left out. The source language outcome must be a qualified success.

In past decades, the translation task was usually carried out by professional translators. However, with the boom of communication technologies, this is not the case anymore. Accordingly, Pérez and Susam (2014) point out that there are complex real-life situations in which people are required to translate and, as a result, there has been an increasing number of non-professionals who translate in a lot of different contexts and in more diversified forms.

As part of the English faculty at the ITCR, I often see students use different tools from printed dictionaries to online tools for translation. Students are required in their majors to read and study professional articles and materials in English. This does not mean that they have the linguistic proficiency to deal with such materials. Thus, in many cases when the students rely entirely on the translation provided by these tools, they seem to have problems understanding the true content and meaning of the texts required.

In the study discussed above, it was found that dictionaries may still be valuable tools in the translation of words. However, when the students need to translate at the phrase and sentence level, other elements as their proficiency, use of correct word order and syntax plus their background knowledge of the content are essential elements to both understanding the text and rendering a translation efficiently.

The results found in this study show that the students, as amateur translators, did not reach an effective level in their translation task. In other words, their tendency to translate English texts related to their majors, using printed or online dictionaries, does not guarantee an effective understanding of the content of the texts. At this point, it is important to consider that the content used for this experiment is, so to speak, easier to translate than the technical English texts that they encounter in the courses of their majors. Thus, if these students do not have the expertise of a professional translator, a higher level of competence in the English language would be more useful for them in their English- language-related academic endeavors. It can then be hypothesized that for a more effective understanding of the academic content, and as future engineers and administrators, effective English language learning plays a more significant role than using printed or online translation tools.

\section{Bibliography}

Aparicio, A. and Durbay, C. (2005). Translation. Getting it right. American Translators Association.

Barrachina, S., Bender, O., Casacuberta, F. \& Cibera,J. (2009). Statistical Approaches to Computer Assisted Translation. The MIT Press Journal. British Council. (2018) English Levels. Retrieved from https://www.britishcouncil. es/en/english/levels. 
Collins Cobuild Advanced Dictionary of American English. (2007). Boston, Mass.: Thomas Heinle.

Diccionario de la Lengua Española. (2014). 23. ${ }^{a}$ Edición. Madrid: Real Academia Española. Retrieved from: http://dle.rae.es/

Diccionario Español-Inglés Merrian -Webster. (2014). Springfield, Mass.: Merriam Webster Inc.

Folaron, Deborah. (2010). Networking and Volunteer Translators. Handbook of Translation Studies. John Benjamins Publishing Company: Philadelphia.

FXM Traduction. Computer Translation: The Status Today. Retrieved from http://www.fxm.ch/En/Langues- Traduction/TraductionOrdinateur.en.htm

Gouadec, D. (2007). Translation as a Profession. Philadelphia: John Benjamins Publishing Company.

Izwaini, S. (2012). Papers in Translation Studies. Cambridge Scholars Publishing.

Keller, M. \& Schechter, S.. (2000). Cognition and Advising. The Mentor. Pennsylvania: Penn State's Division of Undergraduate Studies.

Newmark, P. (2003). A textbook of translation. Prentice Hall International.

Ornstein, R. (1991). Evolution of Consciousness. New York: Simon and Schuster.

Paz, O. (1971). Traducción, Literatura y Literalidad. Barcelona: Tusquets Editor.
Crespo, M. (ed). (2014). Crowdsourcing and Online Collaborative Translation. Philadelphia: John Benjamins Publishing Company.

Petrelli, S. (2003). Translation, Translation. Approaches to Translation Studies. New York: Editions Rodopi.

Presas. (2000). Testing and Assessment in Translation and Interpreting Studies. Edited by Claudia V. Angelelli and Holly E. Jacobson. Philadelphia: John Benjamins Publishing Company.

Richards, J.C., Platt, J. \& Platt, H. (1992) Dictionary of Language Teaching \& Applied Linguistics. Essex: Addison. Wesley Longman Limited. Schaffner, C. \& Adab, B. (2000). Developing Translation Competence. Aston University Birmingham. Philadelphia: John Benjamins Publishing Company.

Somers, H. (2003). Computers and Translation. A translator's guide. Philadelphia: John Benjamins Publishing Company.

Tapiero, I. (2007). Situations Models and Levels of Coherence: Toward a definition of Comprehension. Mahwah, New Jersey: Lawrence Erlbaum Associates Publishers.

Vlasta Vitek, S. (2000). Reflections of a Human Translator on Machine Translation. Translation Journal. Volume 4, Number 3. 


\section{Appendix I \\ Questionnaire}

LE AGRADECEMOS SU RESPUESTA A LAS SIGUIENTES PREGUNTAS.

\section{Parte I}

1. ¿Ha llevado usted cursos de traducción?

Sí No

2. Si su respuesta es afirmativa, dé el nombre de la institución?

3. ¿Ha hecho usted traducciones?

Sí No

4. Si su respuesta es afirmativa, mencione los temas que ha traducido.

5. ¿Qué carrera estudia en el Instituto Tecnológico?

6. ¿En qué año está?

7. ¿Cuál es su rango de edad? Por favor, marque con una "X".

$16-18$

19-21

$22-25$

\section{Parte II}

1. ¿Qué partes del párrafo le han ayudado a inferir el nombre del personaje o hecho histórico al que este se refiere?

2. ¿A qué acontecimiento histórico se refiere este párrafo? 


\section{Appendix II \\ Passage}

\section{Instrucciones: Traduzca al español el siguiente párrafo.}

With the hocked gems financing him, our hero bravely defied all scornful laughter that tried to prevent his scheme. "Your eyes deceive," he had said.

"An egg, not a table, correctly typifies this unexplored planet." How three sturdy sisters sought proof. Forging along, sometimes through calm vastness, yet more turbulent peaks and valleys, days became weeks as many doubters spread fearful rumors about the edge. At last, from nowhere winged creatures appeared signifying momentous success.

\section{Appendix III Students' Translations of the passage}

The following are the translations that the seven students made for the given passage.

\section{Student 1}

Con las gemas empeñadas financiándolo, nuestro héroe desafió valientemente toda risa despreciativa que intentó evitar su plan. "Sus ojos engañan" ha dicho. "Un huevo, no una mesa, simboliza correctamente este planeta inexplorado." Como tres hermanas robustas buscaron pruebas forjando a lo largo, a veces a través de la inmensidad de la calma, cúspides y valles más turbulentos aún, los días se convirtieron en semanas como muchos desconfiados despliegan rumores aterradores acerca del borde. Por fin, de la nada aparecieron creaturas aladas indicando éxito fatídico.

\section{Student 2}

Con la financiación de las piedras preciosas (gemas), nuestro héroe desafió toda risa despreciable que trató de evitar su proyecto. Sus ojos engañan había dicho él. "Un huevo, no una mesa, correctamente tipifica un planeta inesperado." Como tres fuertes hermanas buscaron pruebas. Forjando a lo largo, a veces mediante una inmensa tranquilidad aún más turbulentas cumbres y valles, los días se convirtieron en semanas como muchos escépticos difunden espantosos rumores sobre el borde. Al final, de algún lugar aparecieron creaturas aladas.

\section{Student 3}

Con el empeño de las gemas él obtuvo financiamiento nuestro valiente héroe que desafió las risas despreciativas que trataron de evitar su proyecto "sus ojos engañan" dijo él. "Un huevo, no una mesa representa este inexplorado planeta" como tres fuertes hermanas buscaron la prueba siguiendo adelante, 
algunas veces calmando la inmensidad del pensamiento, más turbulentas cumbres y valles aún, los días se convirtieron en semanas como las dudas se extendieron en espantosos rumores acerca del final. Por último, de ningún lugar aparecieron criaturas aladas anunciando el momento del éxito.

\section{Student 4}

Financiándose con las joyas empeñadas, nuestro héroe valientemente defendió superiormente en broma para intentar prevenir este plan. "Tus ojos engañan" él ha dicho. "Un huevo, no una mesa, correctamente representan el planeta inexplorado" Así es como tres fuertes hermanas buscan pruebas. Forjando a lo largo, algunas veces a través de una calmada inmensidad, más cimas y valles turbulentos, días se volvieron semanas como muchos dudosos expandieron temerosos rumores sobre el borde. Por último, desde alguna parte creaturas con alas aparecieron significando un importante éxito.

\section{Student 5}

Con las gemas empeñadas financiándolo, nuestro valiente héroe defendió todas las risas despreciativas que intentaban prevenir su plan. "tus ojos engañan" él ha dicho. "Un huevo, no un mesa tipifica correctamente este inexplorado planeta" Como tres fuertes hermanas buscan probarlo. Forjando solo, algunas veces a través de inmensa calma, Aún más turbulentos picos y valles, los días se convirtieron en semanas, así como se propaga la incertidumbre de temerosos rumores sobre la era. Finalmente, desde ninguna parte creaturas aladas aparecieron significativamente momentos de éxito.

\section{Student 6}

Financiándose con gemas empeñadas, nuestro héroe valientemente desafió todas las risas despreciativas que trataron de prevenir su plan. "Tus ojos engañan", dijo. "Un huevo, no una mesa, representa correctamente este inexplorado planeta." Como tres fuertes hermanas buscan pruebas. Forjando adelante, a veces a través de la inmensa calma, aún más turbulentas altos y bajos, los días se convierten en semanas como muchos dudosos esparcen aterradores rumores sobre el borde. Por fin, desde ningún lado, criaturas con alas aparecieron como significado del importante éxito.

\section{Student 7}

Con las gemas empeñadas financiándolo, nuestro valiente héroe desafió todos los desdeños burlosos que trataban de prevenir su plan. "Tus ojos engañan" Él había dicho. "un huevo, no una mesa correctamente representan este planeta inexplorado." Como tres robustas hermanas buscan prueba. Forjan juntas, a veces dentro de la calma inmensidad, a veces en turbulentas cumbres y valles, los días se convierten en semanas como muchos dudosos esparcen rumores miedosos sobre el fin. Al menos por ninguna parte criaturas aladas aparecen satisfaciendo un éxito momentoso. 
